Bratten Judith H., Kilanowska Jolanta. Physical education and new forms of activity following the implementation of the core curriculum in Norway in 2020. Journal of Education, Health and Sport. 2021;11(12):56-68. eISSN 2391-8306. DOI http://dx.doi.org/10.12775/JEHS.2021.11.12.005

https://apcz.umk.pl/JEHS/article/view/JEHS.2021.11.12.005

https://zenodo.org/record/5763191

The journal has had 40 points in Ministry of Education and Science of Poland parametric evaluation. Annex to the announcement of the Minister of Education and Science of December 1, 2021. No. 32343. Has a Journal's Unique Identifier: 201159. Scientific disciplines assigned: Physical Culture Sciences (Field of Medical sciences and health sciences); Health Sciences (Field of Medical Sciences and Health Sciences).

Punkty Ministerialne z 2019 - aktualny rok 40 punktów. Zalącznik do komunikatu Ministra Edukacji i Nauki z dnia 1 grudnia 2021 r. Lp. 32343. Posiada Unikatowy Identyfikator Czasopisma: 201159. Przypisane dyscypliny naukowe: Nauki o kulturze fizycznej (Dziedzina nauk medycznych i nauk o zdrowiu); Nauki o zdrowiu (Dziedzina nauk medycznych i nauk o zdrowiu).

(1) The Authors 2021;

This article is published with open access at Licensee Open Journal Systems of Nicolaus Copernicus University in Torun, Poland

Open Access. This article is distributed under the terms of the Creative Commons Attribution Noncommercial License which permits any noncommercial use, distribution, and reproduction in any medium,

provided the original author (s) and source are credited. This is an open access article licensed under the terms of the Creative Commons Attribution Non commercial license Share alike. The authors declare that there is no conflict of interests regarding the publication of this paper.

Received: 15.11.2021. Revised: 25.11.2021. Accepted: 07.12.2021.

\title{
Physical education and new forms of activity following the implementation of the core curriculum in Norway in 2020
}

\section{Judith H. Bratten, Jolanta Kilanowska}

\author{
${ }^{1}$ Judith H. Bratten \\ Faculty of Education and International Studies \\ Department of Primary and Secondary Teacher Education, Oslo Metropolitan University, Norway \\ ${ }^{2}$ Jolanta Kilanowska \\ Faculty of Education and International Studies \\ Department of Primary and Secondary Teacher Education, Oslo Metropolitan University, Norway
}

\begin{abstract}
Teaching physical education is intended to stimulate lifelong joy of movement for students and help them to master life. The core elements of this subject and the interdisciplinary topic of health and life skills, introduced in the new core curriculum (i.e., Fagfornyelsen 2020), enable a broader understanding of students' holistic development.

This article aims to highlight how using movement activities such as yoga, qigong, massage, expressive dance, and visualisation and relaxation techniques, collectively referred to as activities with low pulse and little exertion, can contribute to achieving the aforementioned goals.

In 2017, one of the authors conducted an autoethnographic study at the secondary school in Norway where she worked (Bratten, 2017). She studied which feelings and experiences stood out as meaningful ones for students and teachers in activities with low pulse and low exertion, hereinafter referred to as LpLe-activities. The results were divided into the following categories: different, bodily experiences, and usefulness. The phenomenological approach and Shusterman's theory of somaesthetics were used to clarify the findings.

This discussion demonstrates that the aforementioned activities can create inner security and give students faith in themselves and contribute to goal achievement in physical education. This happens through good and deep sensory experiences and inner experiences that students get in the classes. Such an approach to physical education teaching, focussing on what occurs in the body, has been untraditional and requires knowledge and teachers' desire to enrich the traditional practice of the subject.
\end{abstract}

Key words: life skills, bodily experiences, somaesthetics, physical education 


\section{Introduction}

The implementation of the new core curriculum in Norway, hereinafter referred to as Fagfornyelsen 2020, which is an amendment of the 2006 core curriculum, hereinafter referred to as Kunnskapsløftet 2006, facilitates greater use of varied forms of activity and teaching in physical education. This article aims to highlight these "new" forms of activity and goal achieving other than what was the tradition in the subject for decades.

The concept of lifelong joy of movement has been forwarded from Kunnskapsløftet 2006 to Fagfornyelsen 2020. A new element in Fagfornyelsen 2020 is the emphasis that physical education should contribute to learning life skills. Standal, Moen and Westlie (2020) claim, in connection with the concept of lifelong joy of movement, that research on the subject should focus more on which teaching methods are appropriate when emotional development and learning are to occur. Nordtug and Engelsrud (2017) indicate that when mental health is to be focused on and life skills are to be learned, it is best to take life as a set point. Physical education is considered an arena where students can feel themselves and others through bodily experiences, draw on their own emotions, and so give them bodily expressions.

In this article, we initially revisit physical education in Norway to clarify how the focus in the subject has changed over time. We draw on the traditions in the subject and refer to discussions on the subject that occurred in academic environments in recent decades. We then present parts of Fagfornyelsen 2020 which discuss the core elements of physical education and the interdisciplinary topic of health and life skills.

One of the authors, JHB, worked as a physical education and sports teacher at Norwegian schools for 35 years. During this time, she focused her efforts on providing students experiences with activity forms such as yoga, qigong, massage, expressive dance, visualisation, and relaxation techniques. LpLe-activities eventually became a collective term for these forms of movement. In connection with her master's thesis, which she wrote in 2017, JHB conducted an autoethnographic study of these activities, focussing on which feelings and experiences stood out as meaningful ones for students and teachers. Some of the results of this study are included in this article and form the starting point for our discussion on how LpLeactivities can help realise the content of the core elements and the interdisciplinary topic of health and life skills. The following question guides this article: How can activities with low pulse and little exertion help realise the assumptions of the two core elements, 'movement and bodily learning' and 'participation and interaction in movement activities', as well as the interdisciplinary topic of health and life skills?

\section{Physical education in Norway}

According to the School Act of 1936 and the National School Plan of 1939, physical education was introduced as a compulsory subject for boys and girls. Gurholt \& Steinsholt, (2010) identify several polarities in Norwegian physical education history, claiming that the relationship between predetermined and natural movement, between a disciplining and controlling view on physical education and an open, playful approach to bodily all-round development, runs like a common thread through the literature. From 1925 to 1960, the goal of physical education gradually changed from concentrating on character formation to focussing mostly on health education. Shared shower facilities became a natural part of school facilities in the 1960s; however, using a common shower was, and remains, a controversial issue for schools (Augestad, 2003; Bjørnebekk, 2015; Moen, Westlie \& Skille, 2017). Physical education changed during the 1960s and '70s from a so-called scientific approach to an interest in children's motivation and joy. Focus on this change was very important when a new curriculum for the subject was implemented in 1974 (Solenes, 2010). New curricula and 
changes were also introduced in 1987 and 1997; nevertheless, they did not introduce significant changes to physical education.

Changes in the assessment method that have been implemented over time have affected the subject's content. Following the introduction of Kunnskapsløftet 2006, students' efforts were less emphasised, while skills and results received more space in the assessment (Vinje, 2016). In 2012, the plan was revised; the attitude and effort aspects returned stronger in the assessment. In addition, strong directives stated that testing physical skills should not be used as a part of the grounds for assessment (Utdanningsdirektoratet, 2012). In the autumn of 2020, Fagfornyelsen was introduced. Discussions on the consequences of this new curriculum for the content and assessment methods of physical education have since arisen (Evensen, 2020; Aasland, Moen \& Mathisen, 2020).

\section{Physical education following Fagfornyelsen 2020}

A recent research project on in-depth learning at secondary schools in Norway reveals that teachers and students are concerned with physical education's contribution to students' joy of movement. The subject can also contribute to social learning and health and training (Standal et al., 2020).

Gurholt and Steinsholt (2010) explain that a dualistic view on human beings had governed the content and teaching methods of physical education. They wanted a change to a holistic view. Standal (2015) argues that in traditional physical education, the moving body becomes a learning object when skills, techniques, and knowledge of physical activity are to be developed. He points out that the body is also the knowing subject in physical education and argue for teaching based on an individual student's experience in their body.

In our opinion, the curriculum for physical education in Fagfornyelsen 2020 includes content that has changed the subject to the one that the researchers have requested. According to the curriculum, 'the subject shall help the pupils to learn, sense, experience, and create with their bodies' (Utdanningsdirektoratet, 2020). Attention is focused on an individual student's experience. Concerning the core element of movement and bodily learning, 'the pupils shall explore their own identity and their self-image' (Utdanningsdirektoratet, 2020). The teacher's task is to create a learning environment where it feels safe to sense and explore oneself. Another core element of participation and interaction in movement activities, where students should 'be open to differences and including everyone, regardless of background and abilities', reinforces the sport's fair play concept and competence aims (Utdanningsdirektoratet, 2020). The forms of movement and organisation of teaching should therefore largely enable all students to feel that they can master the situation.

The Ludvigsen Committee, which in 2015 was responsible for designing the new elements in Fagfornyelsen 2020, proposed health and life skills as one of three interdisciplinary topics in the renewal of the Kunnskapsløftet 2006. The committee justified this proposal as follows: 'School's social responsibility comprises more than competence objectives in subjects. School must also support the students' identity development, facilitate good interpersonal relationships, and work systematically with the social environment in school' (NOU 2015: 8, p. 9). Life skills depend on a good and true relationship with oneself and others, and are essential for well-being in life (Sælebakke, 2018).

In the curriculum for physical education, it is formulated under the interdisciplinary topic of health and life skills that 'The pupils shall also learn to treat health as a resource in a way that benefits each individual and learn to make choices that are good for their own and others' 
health throughout life' (Utdanningsdirektoratet, 2020). Health is described as a resource that depends on the choices a person makes. A salutogenic health concept explains health as a variable state. In this perspective, good health is not about the absence of disease but what resources one has to cope with prosperity and adversity to live a life (Antonovsky, 2012).

In a report from the Norwegian Children and Youth Council (LNU), life skills are described as:

the development of skills and practical knowledge acquisition that help the individual to deal with prosperity, adversity, personal challenges, serious events, changes, and conflicts in the best possible way. Creation of a sense of security and belief in one's own abilities to master life, also in the future. (LNU, 2017, p. 9)

The report refers to Bandura's theory of self-efficacy and emphasises that one's belief in mastering life affects one's power and willingness to act.

\section{Activities with low pulse and little exertion}

What is special about LpLe-activities is that they can be performed calmly, with little exertion, and attention drawn to the body. Movements from yoga and qigong are named after animals, plants, and various natural phenomena. During the implementation of the exercises and relaxation, language is used so that images and experiences are visualised for the students, creating a sensual experience. In dance and massage, emphasis is on the students communicating with one another almost without words. During these lessons, the students practice recognising inner experiences in their bodies and sensing themselves and their surroundings better. The aim of this teaching is that the students, in contrast to perform, should focus on inner experience with the purpose of experiencing more, new and different bodily conditions than they usually do (Standal \& Bratten, 2021). Such activities can also help make learning skills easier (Shusterman, 2012; Standal, 2015). Theory of somaesthetics concerns how to train the body to experience more, and also stronger and deeper, as well as here and now (Shusterman, 2012). He claims that somaesthetics integrates Western philosophy, cognitive science, and somatic science with classical Asian theories of body, mind, and action. Furthermore, he emphasises that forms of exercise from the East (e.g., yoga and qigong) are particularly suitable for this purpose.

Winther and de Jong (2016) argue that emotions are strongly present in sports and movement activities. Contact with emotions can be life-giving for good and effective learning because emotions create commitment. Sports or physical education with respect for the existential and ever-present body and a multidimensional understanding of the body allows many possibilities for development. Such an understanding emphasises the interplay between the mental, physical, emotional, social, cultural, and perhaps spiritual aspects (Winther \& de Jong, 2016, p.6).

\section{Research method}

\section{Environment and selection}

As a physical education and sports teacher, JHB, based on her expertise in the activities, has been concerned with offering students an insight into LpLe-activities. Over time, she experienced that the students provided feedback proving that participation in these activities was meaningful. She also experienced that several of her colleagues questioned whether these 
forms of activity were justified in teaching. The study was conducted on first grade (15-16year-olds) students from a class specialising in sports at a secondary school. During the school year, the students had courses that covered various activities and sports; these courses lasted 12-15 hours and ended with an assessment. The course with LpLe-activities was organised with four times practice and one time theory over five weeks. A group of 37 students was divided into two groups that performed different activities. The way the teaching was organised allowed JHB to conduct the study on two groups of students, with 17-18 students in each group.

JHB obtained the school principal's permission to conduct the study, which was explained to the students in advance. All students received and signed a form emphasising voluntary participation at the beginning of the first lesson. All questions related to the study were raised during the lessons.

\section{Choice of method}

Through the study, the teacher (JHB) wanted to gain information on her, and the students' feelings and experiences related to LpLe-activities. JHB decided that using a phenomenological approach would be best. Phenomenology is based on subjective feeling and attempts to gain an understanding of the deeper meaning of this inner experience and feeling in the individual world of experience. It is also based on the assumption that reality is as one perceives it (Thagaard, 2010). One should consider the perceived reality a starting point and try to set aside their understanding to encounter the phenomenon as if it was new. Phenomenology is well suited for describing complex phenomena since it can describe common features of human inner experiences. Pithouse, Mitchell and Weber (2009) claim that self-study can be valuable when one wants to analyse and improve their teaching. The autoethnographic method was suitable for the study. Baarts (2020) defines autoethnography as follows:

The very concept of autoethnography refers to the spectrum from the personal to the cultural. Auto means 'self' and therefore represents introspection, where a researcher makes oneself the object of observation, reflection, and investigation. Ethno means 'culture' and reflects the extrospection itself, where the researcher directs [one's] own attention to those who are studied and the context in which their actions and experiences are created, and where the researcher is also shaped. Finally, graphics refers to the scientific process, the qualitative study, and the systematics where personal narratives, experiences, and observations transform from personal insights to scientific knowledge. (p. 141)

This method requires reflection. The recording of data could occur before and after the lessons. JHB wanted to reflect on her actions and experiences in interaction with the students. In other words, she could study herself in interaction with the students and gain access to her inner experiences.

\section{Data collection}

Data was collected and produced in three different ways:

- Part of the material consisted of the teacher's logged experiences and reflections from the planning of the teaching, and the teaching situation with the students; part of this material was rewritten into several 'frozen' stories.

- The students' reflective logs based on questions that were raised before or after practical teaching. 
- Students' individual or collaborative computer-written answers, collected in the last hour of the course.

The submission of the answers for use in the research context was anonymised and not used to assess the students. Questions that should lead to the teacher's reflection were marked in the $\log$ with 'What did I mean by what I did?' In addition, some of the material was marked as momentary situations (i.e., those that affected the teacher emotionally).

The questions posed to the students had two purposes: The students were to reflect on what they had experienced to improve learning in relation to the goals set for the course. The second purpose was to gather more information for the research. One part of the data collection was performed with predetermined questions. When situations that were interesting to explain arose, the questions were formulated spontaneously. The questions were presented orally before, during or after classes, and the students answered them individually. The data collection ended with a teaching situation that served as a group interview.

After the practical teaching was completed, both groups were gathered for theory teaching. Here, a lecture on different views on the body and on the concept of health was delivered. A group discussion was then conducted and following the interview, the students were asked to answer questions in writing and could deliver their answers anonymously. The students were thus encouraged to be honest and not fear for their grades. However, those who wanted it gained the opportunity to be seen and heard, and receive personal feedback on their thoughts. During the collection, JHB experienced that those observations and reflections provided her with new self-insight into personal and professional aspects. Since the process was demanding, as a kind of self-help, she also wrote stories about herself. Allen-Collinson (2012) indicates that being a researcher while participating in a social group and having to produce texts, perhaps with sensitive content, is demanding. Furthermore, it requires a high degree of critical presence, self-reflection and self-discipline. This process can be experienced as a mentally challenging and emotionally painful self-exploration and is not suitable for the faint-hearted (Allen-Collinson, 2012).

\section{Analysis and interpretation}

Sorting the data was achieved in various ways. In the material from the students, JHB searched for the words that frequently appeared in the answers. The text was coded according to vocabulary, and the words were collected in groups. The question 'What is this all about?' was used during the analysis. Analysing the log was also performed according to vocabulary but not to the same extent as with the students' answers. A holistic view was the basis for interpreting this material. The leading questions were 'What is this all about?', 'What am I interested in?' and 'What have I emphasised?' In this part of the process, it became clear that finding the essence of the forms of activity required that parts of the material be interpreted, not only analysed. During this process, students made many reflections on 'Why did I act the way I did?' The results were presented as a composite text. The study describes detailed situations from the teaching with a focus on the environment, the people, and the tasks. It was important that the students' statements were not distorted or placed in a context that did not match their expressed situations. The authors therefore chose to quote the students word for word and clarify the settings the statements belong to.

\section{Results and discussion}

Following a thematic analysis, the data was divided into the topics of different, bodily experiences, and usefulness. These topics include different sub-topics, which were presented using selected statements from the students, the stories that JHB created, and reflections from 
the teacher herself. We account for the topic of different, while the topics of bodily experiences and usefulness are discussed in relation to the research question.

\section{Different}

In the students' written submissions, the word 'different' was often used to describe what they had experienced. This part of the material contains words with a meaning that can be interpreted as 'different' 'strange', 'unexpected', 'unfamiliar', 'a little special', 'out of comfort', and 'new'.

In LpLe-activities, it was emphasised that the students should gain experiences through their senses and a feeling of inclusion, as one student wrote about dance:

I think the dance was different, fun and a little weird. At first, it was really just a little weird, but eventually, I got in a good mood, and there was a lot of laughter in the room. I felt it was nice to be a little weird since you got in such a good mood from it.

Students described situations where they were assigned tasks that were unfamiliar, challenging, and different than expected. It is clear from the students' statements that they consider being quiet and calm in physical education classes alien and unusual:

'I experienced sitting still with my eyes closed as a bit unfamiliar, meaning that I got a little restless from it'.

'Being in a quiet room when we were really going to have sports was very special'.

Research projects support and explain that this teaching content is untraditional (Crum, 1993; Quennerstedt, 2008; Syvertsen, 2014). The tradition in physical education has dictated that the teacher's task is to trim the students so that they avoid lifestyle diseases. Öhman and Quennerstedt's (2008) study reveals that the following discourses have been linked to the subject: an activity discourse, a social discourse, a physiological discourse, and a sports discourse. The behaviour that was fostered during the classes Öhman and Qennerstedt observed contained the message that students should stand up, participate, do their best, be active and sweat. Recent research on secondary schools confirms that teachers see and evaluate students' efforts based on how sweaty they are, and reward it (Aasland \& Engelsrud, 2017).

In the reflections and log material, JHB often reflected on experiencing herself as different than expected from students and colleagues:

'I try to act quietly, grope and try to act as an equal partner, but at the same time I am the one who controls and sets the framework as a teacher'.

During several of the activities, the students expressed being aware of the conditions in the room. They noticed the silence and the overall atmosphere. The atmosphere, the learning climate, pleasant feelings, and the feeling of community were meaningful for the teacher and the students. The teaching process involved presence and empathy. The teacher's starting point was her ability to sense the students, and rely on her intuition and empathic abilities. Such a role has little in common with a traditional physical education teacher's or coach's role.

Van Manen (2007) and Standal (2015) explain how phenomenological pedagogy involves empathy and sympathy. In Van Manen's pedagogy, the concept of tact is central. The term has two meanings: On the one hand, it means being in tune and functioning as an orchestra. This means that a student and a teacher can interface with each other and must attempt to be 
in step with and follow each other. On the other hand, the term refers to an inflectional form of a tangent, which means to touch, a feeling or an effect (Standal, 2010).

\section{Bodily experiences}

The topic of bodily experiences appeared in the data in the words and expressions that the students used, including 'calm', 'relaxed', 'delicious', 'stretched', 'uncomfortable', 'the feeling on the face', 'concentrated', 'inner peace', 'felt the pulse go down', 'sensed an aroma in the room', 'the others', and 'together'. In the log part of the material, the teacher used 'feel' and 'let go' in connection with the students having to focus on different body parts, emotions, and thoughts. The students, who were often asked to think about and feel in their bodies how they performed a movement and expressed an action in relation to themselves and others, were invited to play. The teacher often used the words 'desire', 'sense', 'vulnerable', 'joy', and 'presence' in her reflection material.

It was common to the teacher and the students that the bodily experiences can be related to the following conditions:

- It is an experience of the room: the music, the aroma and the mood or atmosphere.

- It is an experience of contact with other bodies: touch, glance, and expression.

- It is an experience of one's body when it is at rest or performs stretching movements or the thoughts and the breath inside the body.

- It is an experience of a change in the level of tension in the body occurring, mentally and physically.

- It is an experience of being more present in real time.

- It is something to be learned.

- It is a great deal of joy and an expression of pleasure and presence.

The feelings occurred in contact with oneself and one with others. The feelings influenced and were influenced by the environment around the students. Merleau-Ponty's views on a human intentionally acting with the lived body and their lifeworld as a starting point (Engelsrud, 2006; Heggdal, 2008) were used to explain the students' experiences and feelings. The term 'body awareness' is used in the curriculum for physical education. This concept is known in physiotherapy and special and health pedagogy. The experience with the feelings in this study occurred in an ordinary pedagogical context at a Norwegian school, not in a therapy situation. The analysis demonstrates that JHB emphasised joy and pleasure in the inner experiences. Shusterman's (2012) theory of somaesthetics contains several elements that are suitable to explain bodily experiences as they appear in the data. Play, joy and pleasure are emphasised in the forms of activity, just as joy of movement is emphasised in the school's plans and the concepts of body awareness, sense and well-being are used in Fagfornyelsen 2020.

In classes with LpLe-activities, situations are designed so that students become aware of their inner lives and can mentally, physically, and emotionally focus on tensions in the body through yoga, qigong, massage, and relaxation exercises. When the teacher asked him what he had experienced in a sequence of simple yoga exercises, one student said:

It was nice to have my hands stretched, and besides, I was able to feel the foot that had been broken so intensely. It was really good to stretch there. It's kind of something I would never invent myself just like that.

During the classes, the focus was on communicating with the body. The following account describes how the teacher emphasised that each student should become aware of their appearance, and physically feel whether their appearance matched what they felt inside: 
The students give masculine and feminine expressions in the dance. They use scarves [and] body and facial expressions to chase the others away or ask them to come closer. They are given the task of being proud, sad, scared, angry and happy, and show it with their faces and bodies. They end up with a Haka from the Māori culture.

The students expressed pleasure when the experiences inside their bodies corresponded to what their bodies communicated out:

'The breathing became easier with the expressions. When you have an expression on your face, you get more empathy and manage the movements better'.

Moreover, the students noted that they had a stronger experience when the attention was to be focused on the feeling in the body:

'I loosen up more and feel my hips. It makes me happy'.

Winther and de Jong (2016) describe the emotions in the body, claiming that joy, fear, anger, sadness, and love, to varying degrees, are also present at gyms. Feelings are energies which turn into emotions and have a life function. For instance, anger is a force that can lead to change and help one set boundaries, whereas fear helps one avoid danger and offers them the courage to expand their boundaries. Grief helps one to take things slowly and feel it, while happiness allows one to disconnect from other affairs and become present. These are the different feelings that drive people to action (Winther \& de Jong, 2016). In classes with LpLeactivities, students practise feeling the different forces within themselves. Knowing one's strength and having action competence is a prerequisite for mastering life, as it is described in a report on the interdisciplinary topic of health and life skills: 'Confidence in one's own ability to master tasks and challenging situations is central to how this affects one's own strength, will and ability to act' (LNU, 2017, p. 9).

Feeling small and vulnerable is as human as feeling strong. In modern culture, a trend to view the body as immortal has emerged. People choose to overlook the vulnerable side of being human (Shusterman, 2012; Engelsrud, 2006). In an article that addresses health and life skills, Samnøy and Tjomsland (2021) use the word 'life pain'. The focus is on whether the teacher is a sufficient interlocutor when painful emotions are to be expressed. In lessons with LpLeactivities, the focus is on the students feeling strong and vulnerable emotions in the body. This excerpt from relaxation led by the teacher is a prime example:

Then we will move our attention to another place. Imagine a bluebell, the shape of the flower, the colour and the stem, soft and slender, the growing place in sand by the mountain. I'm talking about how it is strong and vulnerable at the same time. I ask the students to shift their attention back to the body, and instruct in a subdued and clear voice: Feel your head, back and feet. Feel that something inside you can be vulnerable, sad, tired and maybe scared! I ask them to feel their breath and let go. Feel that something inside you is solid, strong, and powerful.

\section{Usefulness}

This study underlines that the content is useful for the students in connection with health and life skills. The students experienced that the learned techniques helped them regulate the tension in the body. The students stated:

'I think everything has made me feel the body and the inner side'.

'What I will take with me is thinking about my breath and sitting quietly thinking about my body'. 
'This course was useful for me because I learned several relaxation exercises that I can use when I am stressed'.

The methods used in classes with LpLe-activities are intended to note the condition in the body and facilitate reflection on the experiences, alone and together. The students in the study specified that they value the forms of activity and highlighted mental and physical conditions in the body that were improved through the activities. They generally described that they felt less stress in the body, became calmer, and gained more energy and presence. It is well known that slow movements and focussing on breath affect the level of stress hormones in the body and increase one's ability to regulate stress and thus master challenges in life (Shusterman, 2012; Shilling, 2012; Antonovsky, 2012; Magelssen, 2008).

It is clear from the study and the following reflection that the teacher is concerned with justifying the content of the teaching based on fair play:

In my opinion, practicing fair play in physical education classes presupposes that the students are able to read other people's body language. What is the other person signalling now? I arrange for the students to have the opportunity to develop their own body language, gain experience in interpreting body language, and through this develop empathy and compassion. I don't think it is sufficient in a learning situation where fair play is central to only demand that the students behave 'properly and correctly'. Learning must be facilitated by feeling, reflection and experience.

Shusterman (2012) argues that ethical codes are mere abstractions until they are granted life through incorporation into bodily dispositions and action. Any properly realised ethical virtue depends not only on some bodily act (speech acts included) but also on having the right somatic and facial expression, indicative of having the right feelings.

Under the core element of participation and interaction in movement activities, it is stated that 'in many movement activities participation, co-responsibility and cooperation are necessary to promote one's own and others' learning. This means being open to differences and including everyone, regardless of background and abilities' (Utdanningsdirektoratet, 2020). This indicates that students must develop empathy, compassion, and respect for others. In LpLeactivities, students practice communicating and empathic actions through bodily touch, as in dance and massage. During classes, it is emphasised that the masseur should heed their body and simultaneously listen to and be aware of the other person's body, adapting the touches so that they become comfortable. The person being massaged should report if something becomes uncomfortable. According to Sælebakke (2018), good empathic abilities are fundamental for developing relationship competences. She claims that such competences are crucial to be able to master life. In the teaching situation created in LpLe-activities, many opportunities for bodily learning related to 'relations with others, the ability to draw boundaries and to respect others' boundaries, and the ability to deal with thoughts, feelings, and relationships' arise (Kunnskapsdepartementet, 2020). Teaching that regards bodily feelings and facilitates reflection on those feelings provides students with an experience of the different forces in the body. We believe that these experiences are resources and tools that students can take with them and use when they master their lives.

The teacher is responsible for implementing good teaching and makes choices that affect the students' inner experiences. A difference between the roles characterises the teacher-student relationship. The differences are such that one can control the other, and the teacher can use power based on a desire to increase students' learning (Tom, 1980). In the student-teacher role, the students depend on teachers who offer them the feeling of security and have learned 
to have an attentive presence in the classroom when the students are to develop their life skills (Sælebakke, 2018).

In the curricula for and research on physical education, it is emphasised that the students' interests and prerequisites should be the starting point for the teaching. Under the core element of movement and bodily learning, it is described that students 'shall enjoy being in movement alone and with others, based on their own interests, intentions, and abilities' (Utdanningsdirektoratet, 2020). In academic circles, it has long been pointed out that if students are to remain active and maintain lifelong joy of movement, they must learn skills that are meaningful to them (Standal, 2019; Crum, 1993). It is not enough to train the students. The core element of movement and bodily learning implies that the student must be involved as an experiencing subject, and the one who is able to reflect (Standal, 2019). If the teacher enables the students to reflect on their experiences in different activities, they will discover what they like, which can help create commitment and lifelong joy of movement in the students.

\section{Conclusion}

Over time, schools have performed social assignments in terms of physical health care, hygiene, and personality formation. Changes in religion, philosophy, political governance, working life, migration, and lifestyles in the population affect the view on human possibilities and help to determine which tasks schools can be required to perform (Gurholt \& Steinsholt, 2010; Augestad, 2003; Solenes, 2010; Bratten, 2017). Physical education was once rooted in sports and scientific theories, which led to a teaching practice where students had to be willing to participate actively and socially in 'the fight against the others' (Öhman \& Quennerstedt, 2008, p. 377).

In our opinion, the content of the core elements and the interdisciplinary topic of health and life skills is a clear reminder that physical education should be based on the whole student, not only the student's body. The physical education tradition with a focus on the teacher training the students and helping them to achieve fit bodies in the face of life's challenges is a tradition that no longer holds.

For several years, the professional circles in Norway have called for content in the subject that emphasises experiences and the emotional aspects of being human and have stressed that physical education can be an arena for such experiences (Nordtug \& Engelsrud, 2016; Standal et al., 2020; Winther \& de Young, 2016). Our research indicates that in LpLe-activities, emphasis is on students' gaining experiences through sensory and inclusive inner experiences so that they can practice feeling and demonstrating emotions, and to gain experience that thought and attention can affect the feelings in the body. The individual student's subjective experience, reflection on their and others' inner experiences and shared inner experiences are prioritised and valued in these classes rather than only physical achievements (Standal \& Bratten, 2021). All students with different feelings and inner experiences are appreciated. This can create inner security and allow the students to have faith in themselves.

Such activities and the focus on what occurs in the body have been an untraditional approach to physical education. It therefore must be practised, and a suitable pedagogical methodology must be used in the classes. It is also important that students in teacher education gain knowledge of these activities and teaching methods, and understand their usefulness in relation to the curriculum.

\section{References}


Allen-Collinson, J. (2012). Autoethnography: situating personal sporting narratives in sociocultural contexts. I K. Young \& M. Atkinson (Red.), Qualitative Research on Sport and Physical Culture (s. 199-212). Bingley, UK: Emerald.

Antonovsky, A. (2012). Helsens mysterium Den salutogene modellen. Oslo: Gyldendal Akademisk.

Augestad, P. (2003). Skolering av kroppen : om kunnskap og makt i kroppsøvingsfaget (PhD. thesis). University of Oslo, Oslo.

Bjørnebekk, W. (2015). Påkledd i dusjen. Oslo: Spartacus.

Bratten, J. H. (2017). Aktiviteter med lav puls og liten kraft $i$ kroppsøvings- og breddeidrettsfaget. "Hvilke opplevelser og erfaringer peker seg ut som meningsfulle for loerer og elever $i$ aktiviteter med lav puls og liten kraft?» (Master's thesis). Oslo Metropolitan University, Oslo.

Baarts, C. (2020). Autoetnografi. I S. Brinkmann \& L. Tanggaard (Red.), Kvalitative metoder En grundbog. København: Hans Reitzels Forlag.

Crum, B. J. (1993). Conventional Thought and Practice in Physical Education: Problems of Teaching and Implications for Change. Quest, 45(3), 339-356. https://doi.org/10.1080/00336297.1993.10484092

Engelsrud, G. (2006). hva er KROPP. Oslo: Universitetsforlaget.

Evensen, K. (2020). Vurdering i kroppsøving. Oslo: Universitetsforlaget.

Gurholt, K. P. \& Steinsholt, K. (2010). Prolog. I K. Steinsholt \& K. P. Gurholt (Red.), Aktive liv Idrettspedagogiske perspektiver på kropp, bevegelse og dannelse (s. 9-34). Bergen: Fagbokforlaget.

Kunnskapsdepartementet. (2020). Overordnet del - verdier og prinsipper for grunnopplaeringen. Hentet fra https://www.udir.no/lk20/overordnet-del/

LNU. (2017). Livsmestring $i$ skolen. Hentet fra https://www.lnu.no/wpcontent/uploads/2017/01/lis-sluttrapport-1.pdf

Magelssen, M. (2008). Pust for livet - Det viktigste helsegrepet du kan ta. Oslo: Cappelen Damm.

Moen, K. M., Westlie, K. \& Skille, E. Å. (2017). Nakenhet som allmenndanning. Norsk pedagogisk tidsskrift, 101(01), 5-18. https://doi.org/10.18261/issn.1504-2987-201701-02

Nordtug, B. \& Engelsrud, G. (2017). Boken som mangler, ord som går på tomgang og sykt flinke jenter: Kunnskap og helse. Tidsskrift for kjønnsforskning, 41(4), 262-278. https://doi.org/10.18261/issn.1891-1781-2017-04-06

NOU 2015:8. (2015). Fremtidens skole - Fornyelse av fag og kompetanse. Oslo: Kunnskapsdepartementet.

Pithouse, K., Mitchell, C. \& Weber, S. (2009). Self-study in teaching and teacher development: a call to action. Educational Action Research, 17(1), 43-62. https://doi.org/10.1080/09650790802667444

Quennerstedt, M. (2008). Exploring the relation between physical activity and health-a salutogenic approach to physical education. Sport, education and society, 13(3), 267283. https://doi.org/10.1080/13573320802200594

Samnøy, S. \& Tjomsland, H. E. (2021). Folkehelse og livsmestring Behovet for en realistisk tilnærming til temaet. Bedre skole, 1, 20-23.

Shilling, C. (2012). Body and Social Theory (3. utg.). London: SAGE Publications Ltd.

Shusterman, R. (2012). Thinking through the Body: Essays in Somaesthetics. Cambridge: Core.

Solenes, O. (2010). Barnekroppen og idretten Ein historisk analyse av barneidretten i Noreg 1937-1976. I K. Steinsholt \& K. P. Gurholt (Red.), Aktive liv Idrettspedagogiske perspektiver på kropp, bevegelse og dannelse (s. 51-69). Bergen: Fagbokforlaget. 
Standal, Ø. F. (2010). Pedagogisk arbeid i rehabilitering: Ei drøfting av praktiske og pedagogiske handlingar. I K. Steinsholt \& K. P. Gurholt (Red.), Aktive liv Idrettspedagogiske perspektiver på kropp, bevegelse og dannelse. Bergen: Fagbokforlaget.

Standal, Ø. F. (2015). Phenomenology and Pedagogy in Physical Education. Abingdon: Routledge.

Standal, Ø. F. (2019). Kva kroppsleg læring eigentleg er. Bedre skole, 3, 56-60. Hentet fra https://www.utdanningsnytt.no/files/2020/07/08/BS0319-WEB.pdf

Standal, Ø. F. \& Bratten, J. H. (2021). 'Feeling better': embodied self-knowledge as an aspect of movement capability Physical Education and Sport Pedagogy. https://doi.org/10.1080/17408989.2021.1886268

Standal, Ø. F., Moen, K. M. \& Westlie, K. (2020). «Ei mil vid og ein tomme djup»? - ei undersøking av innhald og undervisning i kroppsøving på ungdomstrinnet i Noreg Journal for Research in Arts and Sports Education, 4(1), 34-51. https://doi.org/doi.org/10.23865/jased.v4.1749

Syvertsen, K. A. (2014). Helse $i$ kroppsøvingsfaget. «Hvordan forstås helse av kroppsøvingsloerere?» (Master's thesis). Oslo Metropolitan University, Oslo. Hentet fra http://hdl.handle.net/10642/2149

Sælebakke, A. (2018). Livsmestring i skolen Et relasjonelt perspektiv. Oslo: Gyldendal

Thagaard, T. (2010). Systematikk og innlevelse: En innføring i kvalitativ metode. Bergen: Fagbokforlaget.

Tom, A. R. (1980). Teaching as a Moral Craft: A Metaphor for Teaching and Teacher Education. Curriculum Inquiry, 10(3), 317-323. https://doi.org/10.2307/1179618

Utdanningsdirektoratet. (2012). Endringer i faget kroppsøving Udir-8-2012 Hentet fra https://www.udir.no/regelverkstolkninger/opplaring/Innhold-i-opplaringen/Udir-82012/4/42-Vurdering/Bruk-av-tester/

Utdanningsdirektoratet. (2020). Loereplan $i$ kroppsøving ((KRO01-05)). Hentet fra https://www.udir.no/lk20/kro01-05

Van Manen, M. (2007). Phenomenology of Practice Phenomenology \& Practice, 1(1), 11-30. https://doi.org/10.29173/pandpr19803

Vinje, E. E. (Red.). (2016). Kroppsøvingsdidaktiske utfordringer. Oslo: Cappelen Damm Akademisk.

Winther, H. \& de Jong, M. (2016). Grundläggande känslors liv och funktion i undervisningen i idrott och rörelse - en ständig möjlighet till lärande. idrottsforum.org. Hentet fra https://idrottsforum.org/winther160420/

Öhman, M. \& Quennerstedt, M. (2008). Feel good—be good: subject content and governing processes in physical education. Physical Education and Sport Pedagogy, 13(4), 365379. https://doi.org/10.1080/17408980802353339

Aasland, E. \& Engelsrud, G. (2017). "Det er lett å se hvem av dere som har god innsats". Om elevers innsats og lærerens blikk i kroppsøving. Journal for Research in Arts and Sports Education, 1(3), 5-17. https://doi.org/10.23865/jased.v1.889

Aasland, E., Moen, K. M. \& Mathisen, G. (2020). Et fornyet kroppsøvingsfag. Bedre skole, 1, 36-40. 